\title{
Effects of 2,3-Bis(4-hydroxyphenyl)-propionitrile on Induction of Polyovular Follicles in the Mouse Ovary
}

\author{
TOMOMI SATO $^{1,2}$, HANNAH KIM ${ }^{2}$, HANAKO KAKUTA ${ }^{1}$ and TAISEN IGUCHI ${ }^{1}$ \\ ${ }^{1}$ Graduate School of Nanobioscience, and ${ }^{2}$ International Graduate School of Arts and Sciences, \\ Yokohama City University, Yokohama, Japan
}

\begin{abstract}
Background/Aim: Neonatal diethylstilbestrol (DES) treatment induces polyovular follicles (PFs), which contain more than two oocytes in a follicle, through estrogen receptor (ER) $\beta$, not ERa. 2,3-Bis(4-hydroxyphenyl)-propionitrile $(D P N)$ is a specific ER $\beta$ agonist; the effects of neonatal DPN exposure on PF induction and gene expression in the mouse ovary were examined. Materials and Methods: Histological analysis and real-time reverse transcription-polymerase chain reaction were performed. Results: The PF incidence was significantly high in the ovary of neonatally DPN-exposed mice compared to that in oil-exposed mice. The gene expression of growth differentiation factor 9 (Gdf9), Mullerian-inhibiting substance, steroidogenic factor 1 (SfI) and steroidogenic acute regulatory protein (Star) in the ovary was significantly increased in the mice neonatally exposed to $40 \mu \mathrm{g} D P N$ compared to oil-treated mice. Conclusion: Since SF1 is an important transcription factor of several genes involved in ovarian function, up-regulation of Sf1 expression by neonatal exposure to DPN, through $E R \beta$, might affect expression of $G d f 9$, Mis and Star, resulting in increased PFs in mouse ovary.
\end{abstract}

Two types of estrogen receptors (ER), ER $\alpha$ and ER $\beta$ are widely found in mammals including mouse, rat and human. In the mouse ovary, $\mathrm{ER} \alpha$ is localized in the interstitial and thecal cells, whereas ER $\beta$ is mainly localized in the granulosa cells $(1,2)$. ER $\beta$-knockout mice are subfertile due to fewer oocytes even after superovulation, therefore $E R \beta$ is important for follicle maturation from the antral stage (3). However, the

This article is freely accessible online.

Correspondence to: Dr. Tomomi Sato, Graduate School of Nanobiosciences, Yokohama City University, 22-2 Seto, Kanazawaku, Yokohama 236-0027, Japan. Tel: +81 457872394, Fax: +81 457872413, e-mail: tomomi@yokohama-cu.ac.jp

Key Words: Polyovular follicle, diethylstilbestrol, estrogen receptor $\beta$, ovary. role of ER $\beta$ in the neonatal ovary is still unclear. It is reported that neonatal treatment with genistein or diethylstilbestrol (DES) induces polyovular follicles (PFs), which contain more than two oocytes in a follicle, through $\operatorname{ER} \beta$, not $\operatorname{ER} \alpha(1,4)$. These findings indicate that ER $\beta$ in the neonatal mouse ovary can be physiologically activated by ER $\beta$ ligand.

2,3-Bis(4-hydroxyphenyl)-propionitrile (DPN) is a specific ER $\beta$ agonist and exhibits 70-fold greater binding affinity for ER $\beta$ than ER $\alpha$ (5). DPN also exhibits the highest transactivation activity with mouse ER $\beta$ at $10^{-9} \mathrm{M}$ and no significant estrogenic activity for mouse ER $\alpha$. Neonatal exposure to $25 \mu \mathrm{g}$ DPN induced PFs in the mouse ovary at 30 days of age (6). Surprisingly, neonatal exposure to 4,4',4',-(4-propyl-[1H]-pyrazole-1,3,5-triyl) triphenol (PPT), a specific ER $\alpha$ agonist, also induces PFs in the mouse ovary at 30 days, although not having significant estrogenic activity on mouse ER $\beta$ in in vitro transactivation assay (6). These results suggest that both ER $\alpha$ and ER $\beta$ are involved in PF induction, however, ER $\beta$ is essential for PF induction because a lack of ER $\beta$ results in no PF induction in the ovary even after neonatal exposure to DES (4).

PFs are found in the ovary of growth differentiation factor $9(\text { Gdf9 })^{+/-}$bone morphogenetic protein $15(\text { Bmpl5 })^{-/-}$mice, both are oocyte-secreted growth factors (7), and transgenic mice expressing the rat inhibin $\alpha$ (Inha) subunit gene (8). These facts indicate that PF induction can be accompanied with changes in expression of those genes. However, no significant changes in the expression of Gdf9 and Bmpl5 are found in the ovary of mice neonatally exposed to DES at 5 , 20 and 30 days, but only Inha is increased $(4,9)$. Since DES can bind and transactivate both $\operatorname{ER} \alpha$ and $\operatorname{ER} \beta(10,6)$, it is possible that changes in gene expression include all of the genes downstream of ER $\alpha$ and ER $\beta$. Downstream signaling via $\mathrm{ER} \beta$ and $\mathrm{PF}$ has not been elucidated in vivo.

This study examined the effects of neonatal exposure to DPN on the mouse ovary. To study the mechanism of PF induction, the effects of DPN on the mRNA expression of genes possibly involved with PF induction were studied in C57BL/6J mice. 
in vivo $32: 19-24(2018)$

Table I. Sequences of the oligonucleotides used as primers for real-time quantitative RT-PCR.

\begin{tabular}{llll}
\hline Gene & Encoded proteins & Forward sequence $\left(5, \rightarrow 3{ }^{\prime}\right)$ & Reverse sequence $\left(5^{\prime} \rightarrow 3^{\prime}\right)$ \\
\hline Bmp15 & Bone morphogenetic protein 15 & TCCTTGCTGACGACCCTACATT & GGTCAGCCGAACGATGGTATAA \\
Gdf9 & Growth differentiation factor 9 & TGGTGGACCTGCTGTTAACCT & CCAGAAGACATGGCCTCCTTTA \\
Inha & Inhibin alpha subunit & CTGCTCTCAATATCTCCTTCCAAGAG & CCATGGCAGTAGTGGAAGATGATGAA \\
Mis & Mullerian inhibiting substance & CCTACATCTGGCTGAAGTGATATGG & GAGGCTCTTGGAACTTCAGCAA \\
Sf1 & Steroidogenic factor 1 & TTGCCTCCTGAAAGCCACTCT & CGCGAAAGCAGGAAAGACA \\
Star & Steroidogenic acute regulatory protein & GCTGCCGAAGACAATCATCA & GATGGACAGACTTGCAGGCTT \\
Cyp11al & Cholesterol side chain cleavage (P450SCC) & GTGAATGACCTGGTGCTTCGT & TCGACCCATGGCAAAGCTA \\
Peptidylprolyl & Cyclophilin A & AGGTCCTGGCATCTTGTCCAT & CCATCCAGCCATTCAGTCTTG \\
isomerase A & & & \\
\hline
\end{tabular}

\section{Materials and Methods}

Animals. Female 20-day-old, 4- and 8-month-old C57BL/6J mice (mean weights 10, 25 and $32 \mathrm{~g}$, respectively) (CLEA Japan, Tokyo, Japan) were kept under $12 \mathrm{~h}$ light $/ 2 \mathrm{~h}$ dark by artificial illumination (lights on $0800-2000$ ) at $23-25^{\circ} \mathrm{C}$. They were fed commercial diet (MF; Oriental Yeast Co., Ltd, Tokyo, Japan) and tap water ad libitum. All animals were maintained in accordance with the National Institutes of Health guide for the care and use of laboratory animals. All experiments were approved by the Institutional Animal Care Committee of the Yokohama City University (YCU-A605). The day of birth was regarded as day 0 of age. Female pups were injected subcutaneously with 20,40 or 60 $\mu \mathrm{g}$ DPN (Tocris Biosciens, Ellisville, MO, USA), $3 \mu \mathrm{g}$ DES (Sigma Chemical Co., St Louis, MO, USA) dissolved in $0.02 \mathrm{ml}$ sesame oil, or the vehicle alone from day 0 to day 4 (5 days).

Histological analysis. Ovaries of 20-day-old C57BL/6J mice treated neonatally with oil, DPN or DES were fixed overnight in Bouin's solution at room temperature. Ovaries were embedded in paraffin, serially sectioned at $8 \mu \mathrm{m}$ and stained with hematoxylin and eosin (HE) stain. Every 13th section of 20-day-old mouse ovaries were observed and the incidence of PFs (\%) was estimated by counting the number of PFs having more than two oocytes per follicle larger than $50 \mu \mathrm{m}$ in diameter per mouse, as described previously (11). The number of mice with PFs in 20-day-old C57BL/6J mice treated neonatally with 20,40 or $60 \mu \mathrm{g}$ DPN, DES or oil vehicle was expressed as the frequency of PFs. Four to five C57BL mice exposed to oil, DPN or DES were used for counting the follicles. Ovaries of 4- and 8-month-old C57BL/6J mice treated neonatally with oil or 20,40 or $60 \mu \mathrm{g}$ DPN were analyzed histologically. Three to eight mice were used for each data point.

Real-time reverse transcription-polymerase chain reaction (RT$P C R$ ). Total RNA was isolated from ovaries of the 20-day-old C57BL/6J mice treated neonatally with oil or $40 \mu \mathrm{g}$ DPN, and reverse transcribed into cDNA by Super Script II reverse transcriptase (Life Technologies, Carlsbad, CA, USA) using 0.05 $\mathrm{mM}$ oilgo dT primer (Life Technologies). Real-time PCR was carried out by a Smart Cycler II System (Takara, Ohtsu, Japan) with SYBR Premix Ex Taq ${ }^{\mathrm{TM}}$ (Takara). Relative mRNA expression of Bmp15, Gdf9, Inha, müllerian-inhibiting substance (Mis), steroidogenic factor-1 (Sf1), steroidogenic acute regulatory protein
(Star) and cholesterol side chain cleavage (Cyp11a1) (Table I) was determined by second derivative method. Peptidylprolyl isomerase $A$ was chosen as an internal standard to control for variability in amplification due to differences in starting mRNA concentration. Melting curve analysis showed a single peak for all samples. Five to ten mice were used for each group and three independent experiments were carried out for each study.

Statistical analysis. Data are expressed as the mean \pm standard error. For multiple comparisons, treatment groups were compared using analysis of variance (ANOVA) followed by Dunnett's post hoc test. Two-tailed Student's $t$-test was used for single comparisons. Fisher's exact probability test was used to examine the significance of the association between the two kinds of classification. A statistically significant difference was defined as that with $p<0.05$.

\section{Results}

In the ovary of mice neonatally exposed to 20,40 or $60 \mu \mathrm{g}$ DPN, all of the stages of follicles developed similar 1 to that of control mice at 20 days of age (Figure $1 \mathrm{~A}$ and B). PFs were found in the ovary of mice neonatally exposed to 40 or $60 \mu \mathrm{g}$ DPN (Figure 1D). The total number of follicles of mice neonatally exposed to DPN was not changed compared with that of the exposed to oil or DES (Figure 2A). The PF incidence was significantly higher in the ovary of mice neonatally exposed to 40 or $60 \mu \mathrm{g}$ DPN compared with that in oil-exposed mice, as well as that in the ovary of mice neonatally exposed to DES (Figure 2B). However, the PF incidence in the ovary of mice exposed to 40 or $60 \mu \mathrm{g}$ DPN was significantly lower than that in the ovary of mice exposed to DES.

Since PFs were significantly induced in the ovary of mice neonatally exposed to $40 \mu \mathrm{g}$ DPN, changes in the gene expression were examined by real-time RT-PCR. In the ovary of these mice, the expression of Gdf9, Mis, Sf 1 and Star was significantly increased compared with that of oiltreated mice at 20 days (Figure 3). The expression of Bmpl5, Inh $\alpha$ and Cypllal in the ovary was not changed by exposure to $40 \mu \mathrm{g}$ DPN. 

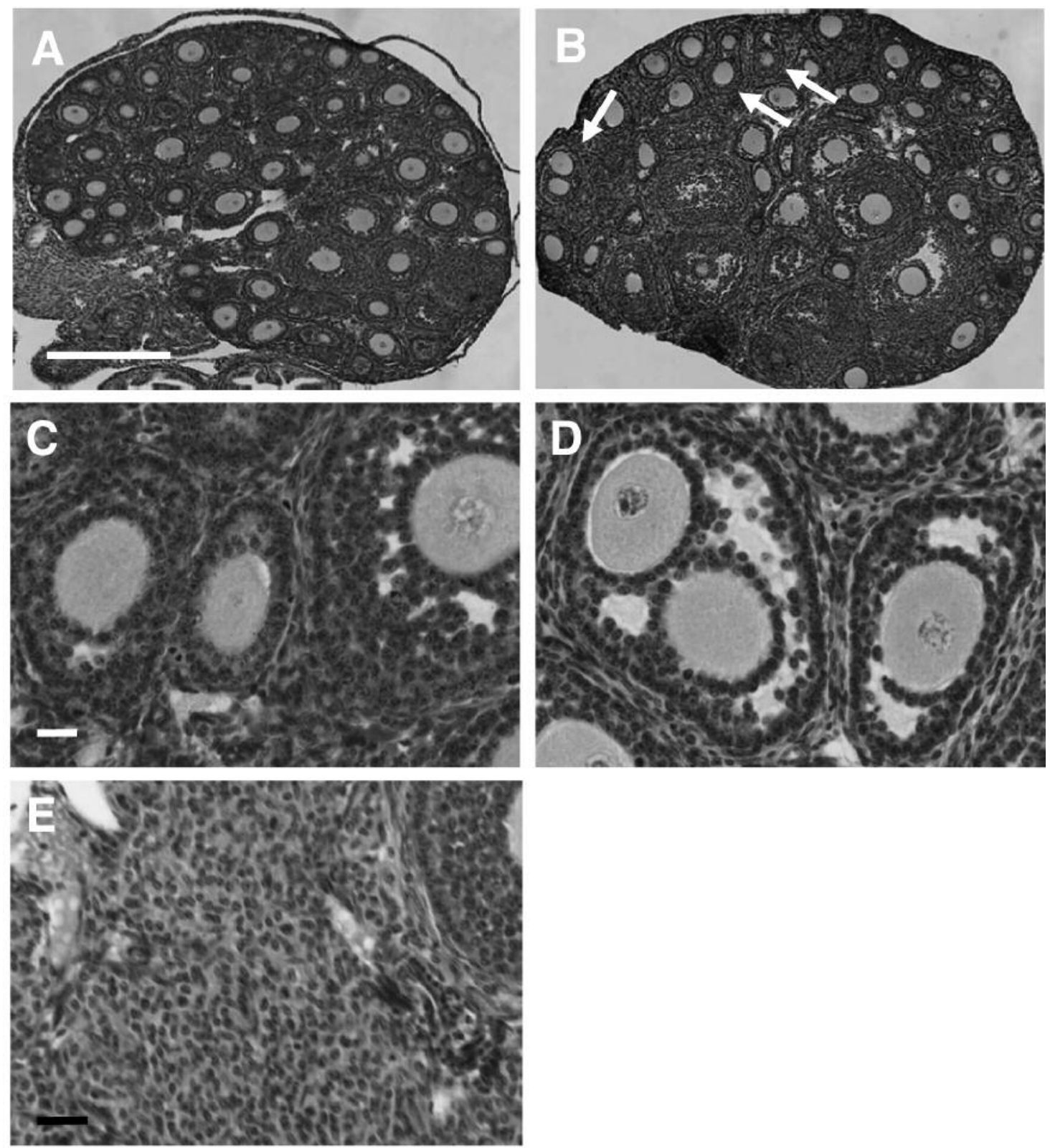

Figure 1. Histology of 20-day-old C57BL/6J mouse ovaries exposed neonatally to oil (A, C), or $40 \mu \mathrm{g}$ 2,3-bis(4-hydroxyphenyl)-propion itrile (DPN) $(B, D)$, and ovaries of 4-month-old C57BL/6J mouse exposed neonatally to $60 \mu \mathrm{g} D P N(E)$. Arrows: Polyovular follicles. Scale bar: A,B: $=200 \mu m$, $C-E: 25 \mu m$.

In the adult ovary, several antral follicles and corpora lutea (CL) were found. At 4 months of age, the ovary of mice neonatally exposed to 20,40 or $60 \mu \mathrm{g}$ DPN showed medullary tubule-like structures, but differences in incidence was not significant. At 8 months, no CL was found in the ovary of mice neonatally exposed to $60 \mu \mathrm{g}$ DPN and all mouse ovaries showed medullary tubule-like structures (Figure 1E, Table II).

\section{Discussion}

Neonatal DES exposure causes several morphological changes in the ovary including PFs, absence of CL, hypertrophy of the interstitial tissue and appearance of hemorrhagic cysts (12). This study demonstrated that DPN induces PFs accompanied with changes in expression of genes possibly involved with PF induction in the mouse 

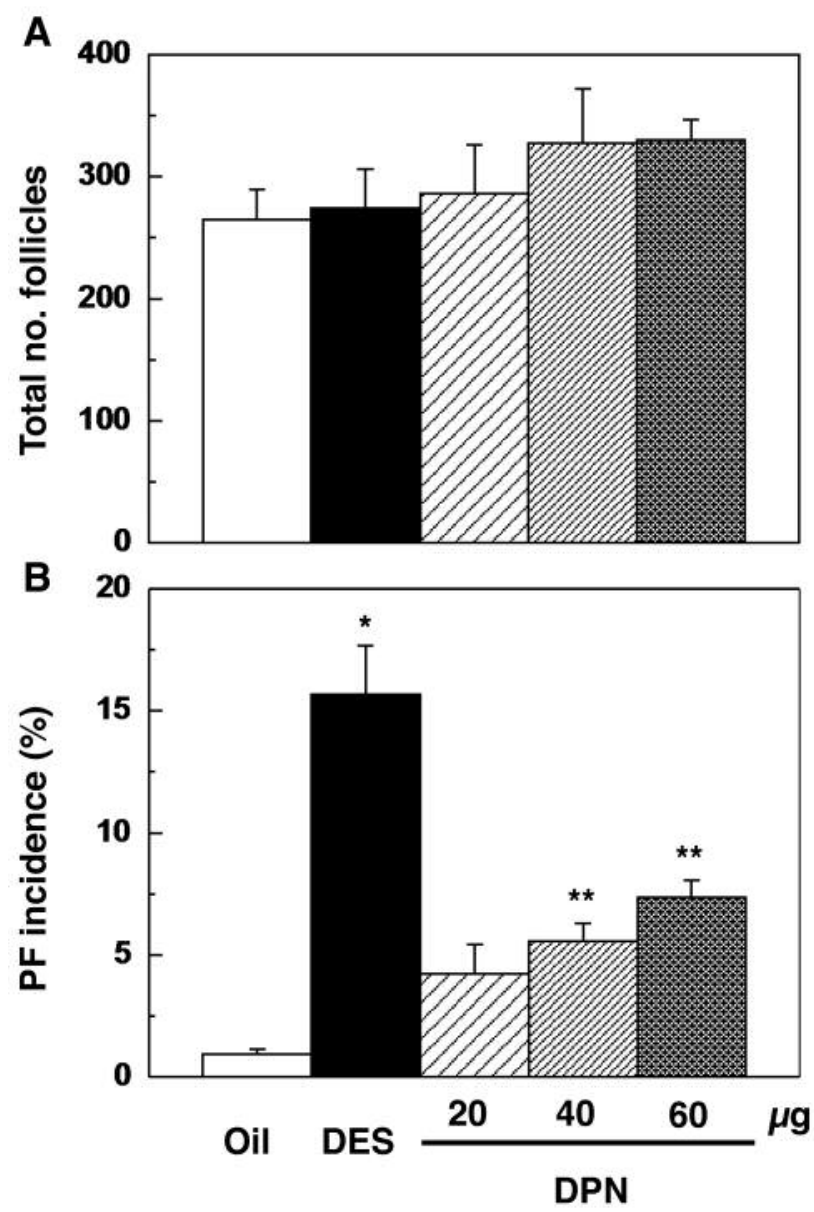

Figure 2. The total number of follicles $(A)$ and incidence of polyovular follicles $(P F)(B)$ in ovaries of 20-day-old C57BL/6J mice exposed neonatally to oil, diethylstilbestrol (DES) or $20 \mu \mathrm{g}, 40 \mu \mathrm{g}$, or $60 \mu \mathrm{g} 2,3-$ bis(4-hydroxyphenyl)-propionitrile (DPN). Significantly different at ${ }^{*} p<0.05$ compared to oil controls, and ${ }^{* *} p<0.05$ compared to mice exposed to DES.

ovary. DPN is a specific ER $\beta$ agonist with high transactivation activity to mouse $\operatorname{ER} \beta$ (5), therefore changes in gene expression can be induced through ER $\beta$. However, exposure to high doses of DPN also led to the formation of medullary tubule-like structures in the interstitial cells of the ovary. Absence of CL and medullary tubule-like structures are due to the alterations of gonadotropin levels, induced by neonatal exposure to DES through $\operatorname{ER} \alpha(13,14)$. Indeed, DPN can transactivate mouse $\mathrm{ER} \alpha$ at $10^{-7}-10^{-8} \mathrm{M}$ in vitro $(6,15)$. Therefore, no CL and an appearance of medullary tubule-like structures in the interstitial cells of the ovary may be an indicator of the effects of DPN via ER $\alpha$. Consequently, ovary of neonatally $40-\mu \mathrm{g}$-DPN-exposed mice was further analyzed for gene expression.

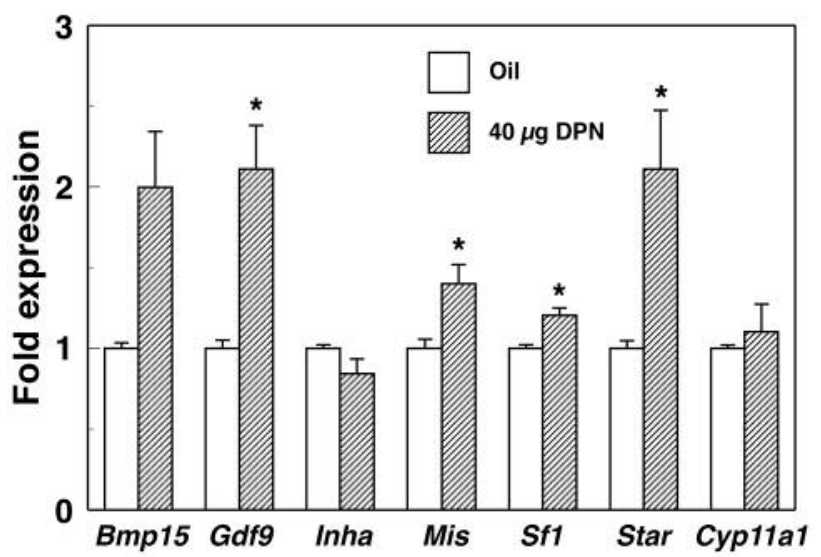

Figure 3. Relative mRNA expression of genes possibly associated with induction of polyovular follicles $(P F)$ in ovaries of 20-day-old C57BL/6J mice exposed neonatally to oil or $40 \mu \mathrm{g}$ 2,3-bis(4-hydroxyphenyl)propionitrile $(D P N)$. *Significantly different at $p<0.05$ compared with oilexposed mice. Bmp15: Bone morphogenetic protein 15; Gdf9: growth differentiation factor 9; Inha: inhibin- $\alpha$; Mis: müllerian-inhibiting substance; Sf1: steroidogenic factor-1; Star: steroidogenic acute regulatory protein; Cyp11a1: cholesterol side chain cleavage.

In the ovary of mice neonatally exposed to $40 \mu \mathrm{g}$ DPN, the expression of Gdf9, Mis, SfI and Star was significantly increased, indicating that these genes are affected by neonatal exposure to DPN. GDF9 is a member of oocyte-derived BMP family which regulates the function of granulosa cells during follicle growth and ovulation as well as BMP15 (16). Gdf9null mice exhibit an absence of normal follicles caused by the loss of granulosa cell proliferation at the end of the primary stage (17). In addition, KIT proto-oncogene receptor tyrosine kinase (Kit) ligand in the granulosa cells and Inha in the primary follicles are highly expressed in Gdf9-null mice (18), suggesting that $G d f 9$ is involved with cell proliferation in the granulosa cells and down-regulation of Inha gene expression during early follicle growth. Indeed, early follicle growth in Inha/Gdf9 double-null ovary is normal (19). Although neonatal exposure to DES cannot alter the expression of $G d f 9$ even at 2 days of age $(4,9)$, dysfunction of granulosa cells by neonatal exposure to DPN through ER $\beta$ may result in an increase of Gdf9. However, although the expression of $\operatorname{Inh} \alpha$ is increased by DES $(4,9)$, it was not changed by neonatal exposure to 40 $\mu \mathrm{g}$ DPN. Thus, an increase of Gdf9 may suppress the expression of Inha even if DPN induces an increase of Inha.

MIS is found in granulosa cells and involved in the entry of primordial follicles into the growing pool (20). SF1 is an essential transcription factor of endocrine development and function, and Mis is a target gene of SF1 (21-23). Although our previous report showed no significant change in the expression of Mis and Sfl in ovaries of mice neonatally exposed to DES (4), neonatal exposure to estradiol benzoate increases Mis mRNA and protein, with inhibition of follicle growth in the rat 
Table II. Effects of neonatal exposure of DPN on the ovary of 4- or 8-month-old mice.

\begin{tabular}{|c|c|c|c|c|c|c|}
\hline \multirow{2}{*}{$\begin{array}{l}\text { Treatment } \\
\text { ( } \mu \mathrm{g} / \text { pup) }\end{array}$} & \multirow{2}{*}{$\begin{array}{c}\text { Age } \\
\text { (months) }\end{array}$} & \multirow{2}{*}{$\begin{array}{l}\text { No. of mice } \\
\text { examined }\end{array}$} & \multirow{2}{*}{$\begin{array}{l}\text { BW } \\
(\mathrm{g})\end{array}$} & \multirow{2}{*}{$\begin{array}{l}\text { Ovarian weight } \\
(\mathrm{mg} / 20 \mathrm{~g} \mathrm{BW})\end{array}$} & \multicolumn{2}{|r|}{ No. of mice with } \\
\hline & & & & & Corpora lutea & Medullary tubule-like structures \\
\hline Oil & 4 & 5 & $24.7 \pm 0.82$ & $3.36 \pm 0.324$ & 5 & 0 \\
\hline $20 \mathrm{DPN}$ & 4 & 5 & $24.0 \pm 0.56$ & $3.99 \pm 0.373$ & 5 & 1 \\
\hline $40 \mathrm{DPN}$ & 4 & 8 & $26.0 \pm 1.37$ & $3.25 \pm 0.148$ & 7 & 1 \\
\hline $60 \mathrm{DPN}$ & 4 & 7 & $24.9 \pm 0.68$ & $3.08 \pm 0.400$ & 4 & 4 \\
\hline Oil & 8 & 5 & $31.4 \pm 1.44$ & $2.31 \pm 0.334$ & 5 & 0 \\
\hline $20 \mathrm{DPN}$ & 8 & 6 & $29.6 \pm 1.93$ & $2.34 \pm 0.280$ & 5 & $4 *$ \\
\hline $40 \mathrm{DPN}$ & 8 & 7 & $31.3 \pm 1.55$ & $2.82 \pm 0.259$ & 5 & 2 \\
\hline $60 \mathrm{DPN}$ & 8 & 3 & $30.5 \pm 2.17$ & $2.81 \pm 0.564$ & $0^{*}$ & $3 *$ \\
\hline
\end{tabular}

BW: Bodyweight. *Significantly different at $p<0.05$ compared to age-matched control mice (Fisher's exact probability test).

at days 6 and 14 (24). In this study, the expression of SfI was also increased in the ovary of mice exposed to DPN, therefore, an increase of Mis may be due to the changes in the SfI expression. Neonatal exposure to DPN possibly plays a role in the function of granulosa cells through ER $\beta$.

MIS is highly expressed in the cuboidal granulosa cells of primary and secondary follicles and decreases in later stages of follicle development (24). In Mis null mice, primordial follicle recruitment is more stimulated $(20,25)$, therefore, an increase of MIS may be correlated with the inhibition of follicle growth. In contrast, neonatal exposure to DES suppresses both primary and secondary follicle progression via $\mathrm{ER} \alpha$ without change in expression of Mis $(4,26)$. In this study, follicle growth in the ovary of mice exposed to DPN is similar to that of control mice, suggesting that an increase of Mis is not necessarily associated with the inhibition of follicle growth. Indeed, mice exposed to DPN were able to ovulate and deliver litters (data not shown). Vitt et al. reported that in vivo treatment with GDF9 stimulated early follicle progression in the rat ovary (27), therefore, an increase in expression of both of Mis and Gdf9 may result in normal follicle development. Several BMPs, including BMP15, significantly induce the expression of Mis in human granulosa cells at mRNA and protein levels, but GDF9 does not (28), suggesting that changes in Mis and Gdf9 expression may not affect each other.

Similarly to Mis, Star expression was also increased in the ovary of mice exposed to DPN, however, localization of these two proteins is different. STAR is mainly localized in the interstitial cells, and both STAR and $\mathrm{P} 450_{\mathrm{SCC}}$ are also decreased in the theca and interstitial cells of rats neonatally exposed to estradiol benzoate (EB) (29). A decrease of expression of these genes is mediated by ER $\alpha$ in the theca and interstitial cells (29), therefore, it is possible that DPN directly affects the expression of Star through ER $\alpha$. However, Star is also a direct target gene of SF1 $(23,30)$, it is also considered that an increase of Star expression may be due to an increase of $S f 1$, as well as Mis.
SF1 is found in the thecal, interstitial, granulosa and luteal cells in the ovary (23). Neonatal exposure to EB also reduces $S f 1 \mathrm{mRNA}$ and protein in the rat through days 6 to 21 (24), however, the expression of $S f 1$ in mice neonatally exposed to DES is not altered through days 10 to 30 (4). Sf1 mRNA is clearly expressed in granulosa cells of most large preantral follicles following treatment with estradiol (31), suggesting that $S f 1$ in granulosa cells is regulated by estrogen. In this study, the expression of $S f 1$ significantly increased in the ovary at 20 days of age in mice exposed to DPN. Although the localization of increased Sf1 expression is not clear, this indicates that the regulation of $S f 1$ is mediated via $\mathrm{ER} \beta$.

In conclusion, neonatal exposure to DPN alters the expression of $S f 1$ through ER $\beta$, and changes in $S f 1$ expression may affect expression of other genes such as Gdf9, Mis and Star. These changes may be involved with PF induction mediated by ER $\beta$. Since several endocrine disruptors such as bisphenol-A can induce PFs (32), further analysis of signaling molecules downstream of ER $\beta$ is important.

\section{Acknowledgements}

This work was partially supported by a Grant-in-Aid for Scientific Research (B) (T.I.), a Grant-in-Aid for Encouragement of Young Scientists and a Grant-in-Aid for Scientific Research (C) (T.S.) from the Ministry of Education, Culture, Sports, Science and Technology of Japan, Grants for Support of the Promotion of Research at Yokohama City University (No. K17030 and W18005 to T.S.), a Health Sciences Research Grant from the Ministry of Health, Labor and Welfare, Japan (to T.I).

\section{References}

1 Jefferson WN, Couse JF, Padilla-Banks E, Korach KS and Newbold RR. Neonatal exposure to genistein induces estrogen receptor (ER) $\alpha$ expression and multioocyte follicles in the maturing mouse ovary: evidence for ER $\beta$-mediated and nonestrogenic actions. Biol Reprod 67: 1285-1296, 2002. 
2 HishikawaY, Damavandi E, Izumi $\mathrm{S}$ and Koji $\mathrm{T}$ : Molecular histochemical analysis of estrogen receptor alpha and beta expression in the mouse ovary: in situ hybridization and Southernwestern histodhemistry. Med Elect Microscop 36: 67-73, 2003.

3 Emmen JM, Couse JF, Elmore SA, Yates MM, Kissling GE and Korach KS: In vitro growth and ovulation of follicles from ovaries of estrogen receptor (ER) $\alpha$ and ER $\beta$-null mice indicate a role for $\mathrm{ER} \beta$ in follicular maturation. Endocrinology 146: 2817-2826, 2005.

4 Kirigaya A, Kim H, Hayashi S, Chambon P, Watanabe H, Iguchi $\mathrm{T}$ and Sato $\mathrm{T}$ : Involvement of estrogen receptor beta in the induction of polyovular follicles in mouse ovaries exposed neonatally to diethylstilbestrol. Zool Sci 26: 704-712, 2009.

5 Meyers MJ, Sun J, Carlson KE, Marriner GA, Katzenellenbogen BS and Katzenellenbogen JA: Estrogen receptor- $\beta$ potencyselective ligands: structure-activity relationship studies of diarylpropionitriles and their acetylene and polar analogues. $\mathbf{J}$ Med Chem 44: 4230-4251, 2001

6 Nakamura T, Katsu Y, Watanabe H and Iguchi T: Estrogen receptor subtypes selectively mediate female mouse reproductive abnormalities induced by neonatal exposure to estrogenic chemicals. Toxicology 253: 117-124, 2008.

7 Yan C, Wang P, DeMayo J, DeMayo FJ, Elvin JA Carino C, Prasad SV, Skinner SS, Dunbar BS, Dobe JL, Celeste AJ and Matzuk MM: Synergistic roles of bone morphogenetic protein 15 and growth differentiation factor 9 in ovarian function. Mol Endocrinol 15: 854-866, 2001.

8 McMullen ML, Cho BN, Yates CJ and Mayo KE: Gonadal pathologies in transgenic mice expressing the rat inhibin $\alpha$ subunit. Endocrinology 142: 5005-5014, 2001.

9 Kim H., Nakajima T, Hayashi S, Chambon P, Watanabe H, Iguchi $\mathrm{T}$ and Sato T: Effects of diethylstilbestrol on programmed oocyte death and induction of polyovular follicles in neonatal mouse ovaries. Biol Reprod 81: 1002-1009, 2009.

10 Kuiper GGJM, Carlsson B, Grandien K, Enmarkr E, Haggblad $\mathrm{J}$, Nilsson S and Gustafsson J-Å: Comparison of ligand binding specificity and transcript tissue distribution of estrogen receptors $\alpha$ and $\beta$. Endocrinology 138: 863-870, 1997.

11 Iguchi $\mathrm{T}$ and Takasugi $\mathrm{N}$ : Polyovular follicles in the ovary of immature mice exposed prenatally to diethylstilbestrol. Anat Embryol 175: 53-55, 1986.

12 Iguchi T: Cellular effects of early exposure to sex hormones and abnormalities of female reproduction. Int Rev Cytol 139: 1-57, 1992.

13 Couse JF, Dixon D, Yates M, Moore AB, Ma L, Maas R and Korach KS: Estrogen receptor-alpha knockout mice exhibit resistance to the developmental effects of neonatal diethylstilbestrol exposure on the female reproductive tract. Dev Biol 238: 224-238, 2001.

14 Kakuta H, Tanaka M, Chambon P, Watanabe H, Iguchi T and Sato $\mathrm{T}$ : Involvement of gonadotropins in the induction of hypertrophyhyperplasia in the interstitial tissues of ovaries in neonatally diethylstilbestrol-treated mice. Reprod Tox 33: 35-44, 2012.

15 Harrington WR, Sheng S, Barnett DH, Petz LN, Katzenellenbogen JA and Katzenellenbogen BS: Activities of estrogen receptor alpha- and beta-selective ligands at diverse estrogen responsive gene sites mediating transactivation or transrepression. Mol Cell Endocrinol 206: 13-22, 2003.

16 Otsuka F, McTavish KJ and Shimasaki S: Integral role of GDF-9 and BMP-15 in ovarian function. Mol Reprod Dev 78: 9-21, 2011.

17 Dong J, Albertini DF, Nishimori K, Kumar TR, Lu N and Matzuk M: Growth differentiation factor-9 is required during early ovarian folliculogenesis. Nature 383: 531-535, 1996.
18 Elvin JA, Yan C, Wang P, Nishimori K and Matzuk MM: Molecular characterization of the follicle defects in the growth differentiation factor 9-deficient ovary. Mol Endocrinol 13: 1018-1034, 1999.

19 Myers M, Mansouri-Attia N, James R, Peng J and Pangas SA: GDF9 modulates the reproductive and tumor phenotype of female Inha-null mice. Biol Reprod 88: 1-6, 2013.

20 Durlinger AL, Kramer P, Karels B, de Jong FH, Uilenbroek JT, Grootegoed JA and Themmen AP: Control of primordial follicle recruitment by anti-Müllerian hormone in the mouse ovary. Endocrinology 140: 5789-5796, 1999.

21 Shen WH, Moor CC, Ikeda Y, Parker KL and Ingraham HA: Nuclear receptor steroidogenic factor 1 regulates the Müllerianinhibiting substance gene: a link to the sex determination cascade. Cell 77: 651-661, 1994.

22 Giuili G, Shen WH and Ingraham HA: The nuclear receptor SF1 mediates sexually dimorphic expression of Müllerian-inhibiting substance, in vivo. Development 124: 1799-1807, 1997.

23 Schimmer BP and White PC: Minireview: steroidogenic factor 1: its roles in differentiation, development, and disease. Mol Endocrinol 24: 1322-37, 2010.

24 Ikeda Y, Nagai A, Ikeda MA and Hayashi S: Increased expression of Müllerian-inhibiting substance correlates with inhibition of follicular growth in the developing ovary of rats treated with E2 benzoate. Endocrinology 143: 304-312, 2002.

25 Visser JA, Durlinger ALL, Peters IJJ, van den Heuvel ER, Rose UM, Kramer P, de Jong FH, and Themmen APN: Increased oocyte degeneration and follicular atresia during the estrous cycle in anti-Müllerian hormone-null mice. Endocrinology 148 : 2301-2308, 2007.

26 Kim H, Hayashi S, Chambon P, Watanabe H, Iguchi T and Sato T: Effects of diethylstilbestrol on ovarian follicle development in neonatal mice. Reprod Tox 27: 55-62, 2009.

27 Vitt UA, Hayashi M, Klein C and Hsueh AJ: Growth differentiation factor-9 stimulates proliferation but suppresses the follicle-stimulating hormone-induced differentiation of cultured granulosa cells from small antral and preovulatory rat follicles. Biol Reprod 62: 370-377, 2000.

28 Ogura-Nose S, Yoshino O, Osuga Y, Shi J, Hiroi H, Yano T and Taketani Y: Anti-Mullerian hormone (AMH) is induced by bone morphogenetic protein (BMP) cytokines in human granulosa cells. Eur J Obstet Gynecol Reprod Biol 164: 44-47, 2012.

29 Ikeda Y, Nagai A, Ikeda M and Hayashi S: Neonatal estrogen exposure inhibits steroidogenesis in the developing rat ovary. Dev Dyn 221: 443-453, 2001.

30 Sugawara T, Kiriakidou M, McAllister JM, Holt JA, Arakane F and Strauss JF 3rd: Regulation of expression of the steroidogenic acute regulatory protein (StAR) gene: a central role for steroidogenic factor 1. Steroids 62: 5-9, 1997.

31 Falender AE, Lanz R, Malenfant D, Belanger L and Richards JS: Differential expression of steroidogenic factor-1 and FTF/LRH1 in the rodent ovary. Endocrinology 144: 3598-3610, 2003.

32 Suzuki A, Sugihara A, Uchida K, Sato T, Ohta Y, Katsu Y, Watanabe $\mathrm{H}$ and Iguchi T: Developmental effects of perinatal exposure to bisphenol-A and diethylstilbestrol on reproductive organs in female mice. Reprod Tox 16: 107-116, 2002.

Received October 12, 2017

Revised October 29, 2017 Accepted November 2, 2017 